\title{
International Refugee Regime: An Alternative Form of Protection for Human Rights Defenders?
}

\author{
Aikaterini-Christina Koula*
}

First published online on 20 August 2021

\begin{abstract}
Human rights defenders (HRDs) are subjected to serious human rights violations through legal and extralegal actions. Notably, most of the abuses against them remain unpunished, perpetuating a vicious cycle of violence against them. There is room for doubt that international human rights law has failed to provide efficient protection for HRDs, and this article considers the international refugee regime as an alternative system of protection. In this sense the article first discusses the intersection between the terms 'refugee' and 'human rights defender' to establish that defenders fall within the protection of the 1951 Refugee Convention. Following an inductive reasoning, the article considers the most well-trodden defects of the refugee regime and the reluctance of HRDs to adopt refugee status; it concludes that this alternative may not be suitable for defenders. Besides a doctrinal approach, the article employs a socio-legal approach, which is enhanced by interviews with HRDs.
\end{abstract}

Keywords: human rights defenders, impunity, protection, 1951 Refugee Convention, refugee law, human rights law

\section{INTRODUCTION}

\subsection{Prologue}

Human rights defenders ${ }^{1}$ (HRDs) play a crucial role in protecting and promoting the realisation of human rights and frequently find themselves and their families at serious risk. International human rights law has failed to provide them with sufficient protection, although the purpose of this article is not to consider the failure of international human rights law. In order to prove this point, however, it describes impunity for crimes committed against defenders as one of the indicative examples of the failure of international human rights law to protect HRDs.

Having no other options, defenders may flee from their countries to escape from violations. As Martin Jones established for the first time in his 2015 article, ${ }^{2}$ HRDs may benefit from international refugee law, as they may fall within the meaning of the term 'refugee' and, as a result, be

\footnotetext{
* Dr Aikaterini-Christina Koula is a Lecturer in Law at the University of Lincoln; AKoula@lincoln.ac.uk. The author is immensely grateful to Dr Anashri Pillay, Mr Martin Jones and Dr Catherine Turner for invaluable comments and feedback on an earlier version of this article. The author is also extremely indebted to all those human rights defenders who spoke with her and shared their experiences. Her sincere thanks go to the anonymous reviewers for their insightful comments. All views expressed in this article and all errors remain those of the author.

${ }^{1}$ The most commonly used term is 'human rights defenders', but the abbreviation 'HRDs' is also widely used. They are also referred to as 'human rights activists' or simply 'defenders'.

${ }^{2}$ Martin Jones, 'Protecting Human Rights Defenders at Risk: Asylum and Temporary International Relocation' (2015) 19 International Journal of Human Rights 935.
} 
entitled to a series of human rights. On this basis refugee law may be an alternative for those defenders who could not find protection and vindication in their country of origin and therefore may seek security in other states. Having adopted an inductive reasoning, the article discusses the most well-trodden flaws in refugee law and, in conjunction with the testimonies of a number of defenders who saw refugee status as a measure of last resort, it concludes that the 'refugee option' is not suitable for defenders. The focus of the article is neither to look at all flaws and irregularities in refugee law nor to suggest initiatives and ways for improving the refugee regime. Rather, it emphasises the most trodden defects as well as the situation of refugee defenders, and argues that even the most common imperfections in the refugee regime can render this alternative option unsuitable for HRDs.

The article starts with the definition of the term 'human rights defenders', emphasising the requirements to be considered a defender. The definition remains one of the most controversial issues in the field of HRDs, and practitioners as well as scholars still explore ways to approach it. In Section 1.2 the article does not go that far, but simply discusses the predominant definition in order for the reader to acquire a good understanding of the intersection between HRDs and refugees. Because the article takes into consideration the opinions of defenders, as expressed in the context of interviews with HRDs, Section 1.3 explains the methodology employed and how the article combines pure doctrinal with empirical research. As stated above, the article considers refugee status as an alternative system of protection, given the inefficiency of international human rights law. Although this failure goes beyond the scope of the article, Section 2.1 gives an example of that failure, presenting impunity as the most obvious example, to highlight the reasons why defenders could make use of refugee law to find security and continue with their lives and activities. In order to benefit from the international refugee regime, defenders should first come within the meaning of the term 'refugee'. Section 2.2 goes through the requirements of the 1951 Refugee Convention and arrives at the conclusion that defenders can be classified as refugees and, as a result, can fall within the protection of international refugee law.

However, the main argument put forward is that this option is not suitable for HRDs for practical and normative reasons. Section 2.3 presents the views of defenders that the refugee regime is a measure of last resort, while Section 3 discusses in detail the most common flaws of refugee law which are sufficient to render this alternative unreliable for individuals like defenders who are already at serious risk. Sections 4.1 and 4.2 examine the reluctance on the part of states to accept refugee defenders, given their activities, as well as the non-ideal situation of those defenders who have been granted refugee status. Having deconstructed the alternative of refugee status and taken into account the inefficiency of human rights law, Section 5 makes recommendations for improving the situation of defenders.

\subsection{Who is a Human Rights Defender?}

The term 'human rights defender' itself implies what these people do in practice; they either speak out against human rights violations, act to promote human rights, or both. HRDs can be persons or organisations that promote human rights. Although the term appears to be 
self-explanatory, there is no formal definition. It is widely accepted, though, that the definition of HRDs derives from Article 1 of the Declaration on $\mathrm{HRDs}^{3}$ and is interpreted in the light of the UN High Commissioner for Human Rights Fact Sheet 29. ${ }^{4}$

According to Article 1 of the Declaration, anyone can serve as a defender of a right and fundamental freedom at any given time. As a result, individuals, groups of persons and organisations may fall within the classification of 'human rights defenders'. Defenders are usually named after the type of human rights for which they fight. For instance, defenders working on behalf of women's rights and on any other gender issue are known as women human rights defenders. ${ }^{5}$ Similarly, those who campaign for a clean, safe and sustainable environment, access to unspoiled natural resources and land rights are known as environmental human rights defenders. In addition, Fact Sheet 29 suggests that a defender should meet three requirements: (i) a defender should accept the universality of human rights; (ii) the defender's arguments should not necessarily be factually or legally correct; and (iii) the defender should promote human rights through 'peaceful actions'. ${ }^{6}$ Fact Sheets are not legally binding, their purpose being to increase knowledge and provide guidance on human rights-related issues; ${ }^{7}$ however, the scope of Article 1 was so unclear that the Office of the UN High Commissioner for Human Rights produced a research report with the aim of providing guidance on the interpretation and application of the Declaration on HRDs.

In fact, the definition derived from the Declaration is considered predominant at the international and regional levels, as it has been adopted and used by the UN Special Rapporteur on the situation of HRDs and all UN bodies as well as the Council of Europe, the European Union, the African Commission on Human and Peoples' Rights and the Organization of American States. ${ }^{8}$

\footnotetext{
${ }^{3}$ Declaration on the Right and Responsibility of Individuals, Groups and Organs of Society to Promote and Protect Universally Recognized Human Rights and Fundamental Freedoms, UNGA Res 53/144 (8 March 1999), UN Doc A/RES/53/144 (Declaration on HRDs).

${ }^{4}$ UN Office of the High Commissioner for Human Rights, Fact Sheet No 29, Human Rights Defenders: Protecting the Right to Defend Human Rights (April 2004) (Fact Sheet 29), https://www.ohchr.org/Documents/Publications/ FactSheet29en.pdf.

${ }^{5}$ Women HRDs are also female activists fighting for any right and freedom.

${ }^{6}$ Fact Sheet 29 (n 4).

${ }^{7}$ Philip Alston and Ryan Goodman, International Human Rights (1st edn, Oxford University Press 2013) 743; Fact Sheet 29 (n 4 ) 7.

${ }^{8}$ UN Committee on Economic, Social and Cultural Rights, Human Rights Defenders and Economic, Social and Cultural Rights (7 October 2016), UN Doc E/C.12/2016/2; UN Economic and Social Council, Report submitted by the Special Representative of the Secretary-General on Human Rights Defenders, Hina Jinali (23 January 2006), UN Doc E/CN.4/2006/95; UN Special Rapporteur on the Situation of Human Rights Defenders, 'How Are Human Rights Defenders Defined?', https:/www.protecting-defenders.org/en/content/how-are-humanrights-defenders-defined; Council of Europe, Commissioner for Human Rights, 'Council of Europe Colloquy on Protecting and Supporting Human Rights Defenders in Europe', 13-14 November 2006, CommDH(2006)2, 1, https://rm.coe.int/09000016806dab16; Council of Europe, 'Conclusions of Council of Europe Commissioner for Human Rights, Mr Thomas Hammerberg: Colloquy on Protecting and Supporting Human Rights Defenders' (13-14 November 2006), Doc CommDH (2006)19, https://rm.coe.int/09000016806da64b; European Union, 'Ensuring Protection: EU Guidelines on Human Rights Defenders' (2004), https://eeas.europa.eu/sites/ eeas/files/eu_guidelines_hrd_en.pdf; African Commission on Human and Peoples' Rights, Res 69 on the Protection of Human Rights Defenders in Africa (4 June 2004), ACHPR/69(XXXV)03; Organization of American States, 'Human Rights Defenders: Support for Individuals, Groups, and Organizations of Civil
} 
It is worth noting that major civil society organisations working with HRDs also rely on the UN definition. ${ }^{9}$

Despite strong acceptance of this definition and the fact that it has been more than twenty years since the adoption of the Declaration, the definition has been heavily criticised for several reasons. The broadness of the definition leaves important issues unaddressed, such as the motives of the individual and the period of activity, as well as the vagueness of the minimum standards. Those factors marked out the parameters of a debate among practitioners and academics. The need for a clearer and less controversial definition is becoming another hotly debated issue. ${ }^{10}$ However, the predominant definition provides a good overview of who falls within the term and allows further discussion of whether a defender can also fall within the definition of the term 'refugee' and, as a result, be entitled to enjoy the rights enshrined in the 1951 Convention. As will be seen from the discussion later in the article, besides the term 'human rights defenders', the term 'refugee' would benefit from reform and clearer requirements, which in turn would contribute to more effective protection of refugees and those defenders wishing to take advantage of refugee status.

\subsection{Methodology}

This article combines a doctrinal approach with socio-legal analysis and, more specifically, with empirical research, providing a holistic approach to the alternative option of refugee status for defenders. In particular, pure doctrinal method is used to explore and discuss rules, principles and academic scholarship relevant to international refugee law and, at times, to international human rights law. It became clear from a critical reading of these sources that refugee status would not be a suitable alternative for HRDs because of the defects of the regime. Interviews with HRDs were conducted to enable the author to consider the opinions of defenders on the possibility of adopting refugee status. In other words, although interviews are not central to the method, the experiences and opinions of participants are considered 'part of the reality' and allow the author to examine this alternative through the HRD lens. The combination of the doctrinal approach and empirical

\footnotetext{
Society Working to Promote and Protect Human Rights in the Americas', San Pedro Sula (4 June 2004), Res AG/RES. 2517 (XXXIX-O/09).

${ }^{9}$ Front Line Defenders and the International Federation for Human Rights (FIDH) are organisations that were founded and work with the specific aim of protecting HRDs and use the definition deriving from the Declaration and Fact Sheet 29; see Front Line Defenders, 'The Front Line Defenders Story', https://www.frontlinedefenders.org/en/who-we-are.

${ }^{10}$ Yvonne Donders, 'Defending the Human Rights Defenders' (2016) 34 Netherlands Quarterly of Human Rights 282; Alice Nah and others, 'A Research Agenda for the Protection of Human Rights Defenders' (2013) 5 Journal of Human Rights Practice 401; Aikaterini-Christina Koula, 'The UN Definition of Human Rights Defenders: Alternative Interpretative Approaches' (2019) 5 Queen Mary Human Rights Law Review 1; International Service for Human Rights (ISHR), 'Model Law for the Recognition and Protection of Human Rights Defenders', 2016, 2, https://www.ishr.ch/sites/default/files/documents/model_law_full_digital_updated_15june2016.pdf.
} 
research leads to the conclusion that the refugee regime is not an ideal alternative not only because of the challenges the regime faces but also because defenders see it only as a measure of last resort.

Empirical research was conducted in February and March 2018 in the context of broader qualitative research on the failure of international human rights law to protect HRDs. Sixteen defenders from across the globe were interviewed by the author, three of whom had already been granted asylum status. More specifically, $50 \%$ of the participants came from Africa and Asia, 25\% from a former Soviet Union state and the rest from South America. Their areas of activity varied depending on the situation and the human rights record of their country of origin. In particular, defenders from a former Soviet Union state appeared to fight against torture, freedom of expression and assembly, while most of the defenders coming from Africa focused on the rights of women, the LGBTQ community, and children. Several participants also fought against state corruption and, having spoken out against government activities and policies, were targeted. In addition, a couple of environmental and indigenous HRDs who tended to fight for land rights took part in the research and contributed with their experience.

HRDs are people in danger based on their activities; most of them may have received many threats, which is likely to make them suspicious of taking part in research by someone they neither know nor trust. Therefore, all participants were approached through non-governmental organisations (NGOs) and centres working with HRDs. Many HRDs refused to take part from fear of persecution and further attacks.

In essence, convenience sampling was employed, as the subjects/participants were chosen based on their accessibility and availability to the author, ${ }^{11}$ regardless of their area of activities, their country of origin and gender. Although it could be argued that this method of sampling is weak because it is a non-probability/non-random sampling method, given the difficulties in approaching participants this technique was the only way to speak with them and take into account their views. In several cases, where participants were unable to answer questions because they did not have relevant experience, they referred to the experience of their friends and colleagues. This practice may also be questioned, but considering the difficulties in finding a good sample size, it can be accepted that it still informs the research by providing valuable information. With regard to refugee status, the vast majority of the participants referred to several of their colleagues who had left their country of origin and sought asylum when asked whether they had used international refugee law to escape from violations.

Interview data was drawn from the interview transcripts and analysed using the qualitative data analysis software Nvivo 12. In this article the research findings are presented, where relevant, with the purpose of supporting the position that HRDs would not find the refugee regime an ideal alternative.

\footnotetext{
${ }^{11}$ Ilder Etikan, Sulaiman Abubakar Musa and Rukayya Sunusi Alkassim, 'Comparison of Convenience and Purposive Sampling' (2016) 5 American Journal of Theoretical and Applied Statistics 1.
} 


\section{Why Refugee Law?}

\subsection{Failure of International Human Rights Law to Protect HRDs}

HRDs are subjected to serious human rights violations such as torture, murder, enforced disappearance and intimidation. ${ }^{12}$ However, most of the abuses against HRDs remain unpunished, ${ }^{13}$ exacerbating the circle of violence against defenders and constituting a major obstacle to their human rights activities and thereby to the realisation of human rights. Impunity is the most obvious example of the failure of human rights law to offer effective protection for HRDs, giving the false perception that human rights violations against HRDs are tolerated, which in turn encourages further abuse.

The violators of defenders' rights can be state authorities as well as non-state actors (NSAs). However, in most cases state authorities are those directly responsible for abuses committed against HRDs. States are, at the same time, the primary duty bearers of human rights obligations and the main perpetrators of rights abuses. The concept of due diligence in international human rights law is different from that in other areas of international law; it focuses on the internal affairs of states and concerns the obligation of the state to refrain from interfering with the exercise of a right as well as the obligation to take all necessary measures to ensure full enjoyment of human rights. ${ }^{14}$ On this basis, if state authorities fail to comply with the obligation to refrain from violating human rights or the duty to create the necessary conditions for enjoyment of such rights, then the state must provide an adequate and effective remedy. Failure to restore the full exercise of human rights means failure to comply with human rights obligations, which in turn means that a state may incur responsibility for violations of treaty provisions.

The responsibility of NSAs for human rights violations is a major area of international human rights law, ${ }^{15}$ which is still evolving and clearly goes beyond the scope of this article. It is sufficient to say at this point that states should focus on their international human rights obligations and particularly on their duty to protect individuals against human rights violations by NSAs within their territory. ${ }^{16}$ Failure to do so might entail responsibility for international human rights.

\footnotetext{
${ }^{12}$ UN General Assembly, Report of the UN Special Rapporteur on the Situation of Human Rights Defenders (Margaret Sekaggya) (4 August 2010), UN Doc A/65/223, paras 5, 10; Fact Sheet 29 (n 4) 10.

${ }^{13}$ Fact Sheet (n 4) 11.

${ }^{14}$ International Law Association (ILA), 'ILA Study Group on Due Diligence in International Law First Report', January 2014, 14; ILA, ILA Study Group on Due Diligence in International Law Second Report, July 2016, 8; IACtHR, Case of Velásquez Rodriguez v Honduras, Judgment of 29 July 1988, para 172.

${ }^{15}$ See, eg, Andrew Clapham, 'The Use of International Human Rights Law by Civil Society Organisations' in Scott Sheeran and Nigel Rodley (eds), Handbook of International Human Rights Law (Routledge 2013) 153; Rachel Brett, 'Non-Governmental Organizations and Human Rights' in Catarina Krause and Martin Scheinin (eds), International Protection of Human Rights: A Textbook (Turku/Abo 2009) 679; Thomas Risse, Stephen Ropp and Kathryn Sikkink, The Persistent Power of Human Rights: From Commitment to Compliance (Cambridge University Press 2013).

${ }^{16}$ Eileen Denza, 'The Relationship between International and National Law' in Malcolm D Evans (ed), International Law (5th edn, Oxford University Press 2014) 393-415; David Harris and Sandesh Sivakumaran,
} 
With regard to HRDs, most of the abuses against them are left unpunished and leave victims without effective remedy, which encourages further violations. In essence, the failure of states to protect defenders in the first place and provide them with an effective remedy for crimes committed against them emphasises the inefficiency of international human rights in addressing impunity. One may find further examples of the inefficiency of human rights law - such as abuse of law as a means of criminalising the activities of HRDs - but, as stated above, impunity is the most indicative example.

\subsection{The Intersection of Refugees and Refugee Human Rights Defenders ${ }^{17}$}

Because of the nature of their work, HRDs are targeted through extralegal and legal actions, such as attacks and enforced disappearances, as well as the adoption of criminal justice policy and the abuse of administrative power. Therefore, many defenders either may choose or are forced to leave their country of origin and seek asylum in another state to escape the violations committed against them. On this basis, and given the inefficiency of international human rights law in protecting HRDs, a possible alternative option is international refugee law, which is a distinct area of law. Their status as refugees would entail a series of human rights to which they would not be entitled otherwise, and keep them safe in the asylum states, as the prohibition of forced removal applies. In order to benefit from refugee status, HRDs should first be characterised as refugees.

Refugees have existed for as long as history, but the Convention relating to the Status of Refugees (known as the 1951 Convention, the Geneva Convention, or the Refugee Convention), adopted on 28 July 1951, ${ }^{18}$ and its 1967 Protocol $^{19}$ provide the most comprehensive codification of refugees' rights, constituting the cornerstone of the international refugee regime. ${ }^{20}$

Cases and Materials on International Law (8th edn, Sweet \& Maxwell 2015); Andrew Clapham, Human Rights Obligations of Non-State Actors (Oxford University Press 2006); Nicolas Carrillo Santarelli, 'Non-State Actors Human Rights Obligations and Responsibility under International Law' (2008) 15 Revista Electronica de Estudios Internationales 1.

${ }^{17}$ The article uses the term 'refugee defender' to refer to those individuals who used to act as defenders in their country of origin, regardless of whether they continue to work as HRDs in their country of residence or have decided to keep a low profile. The author consciously avoids using the terms 'human rights defenders in exile' or 'exiled human rights defenders' (EHRDs) because they are quite broad. In particular, EHRDs may encompass not only HRDs who have been granted refugee status, but also those living in self-imposed exile to safeguard their life and liberty. The latter may not have applied for asylum but live legally within the territory of the state (e.g. by visa or dual citizenship). On the other hand, it is worth noting that McQuaid seems to use the term 'refugee defender' in the same way, but for her it also includes those individuals who started fighting for refugee rights, and human rights in general, once they arrived in their country of residence: Katie McQuaid, 'Defenders Across Borders: Congolese Human Rights Defenders in Uganda's Refugee Regime', Centre for Applied Human Rights, University of York, Human Rights Defender Hub Working Paper Series, Working Paper 4, March 2018, https:/static1.squarespace.com/static/58a1a2bb9f745664e6b41612/t/ 5ad0a19a70a6adbfd8917dbc/1523622302374/HRD+Hub+Working+Paper+No.+4+April+2018.pdf.

${ }^{18}$ Convention relating to the Status of Refugees (entered into force 22 April 1954) 189 UNTS 137 (1951 Convention).

${ }^{19}$ Protocol relating to the Status of Refugees (entered into force 4 October 1967) 606 UNTS 267.

${ }^{20}$ Jane McAdam, 'Interpretation of the 1951 Convention' in Andreas Zimmermann, Jonas Dörschner and Felix Machts (eds), The 1951 Convention relating to the Status of Refugees and Its 1967 Protocol (Oxford University Press 2011) 75. 
The definition in Article 1(A)(2) is the passport to refugee status, which entails formal immigration, the expectation of naturalisation and entitlement to a series of civil, political, economic, social and cultural rights. ${ }^{21}$

Martin Jones, a leading expert on HRDs, argues that particularly HRDs at risk ${ }^{22}$ may fall within the definition of 'refugees' if they decide to flee from their country of origin; this means that a defender under the title of 'refugee' may be entitled to various human rights. ${ }^{23}$

Pursuant to Article 1(A)(2), a refugee must meet four requirements; in particular, they must (i) be outside the country of their nationality; (ii) have a well-founded fear of persecution; (iii) be at risk of persecution on grounds of race, religion, nationality, membership of a particular social group or political opinion; and (iv) must be unwilling to avail themselves of the protection of their country of origin. ${ }^{24}$ The 1951 Convention allows certain individuals at risk to be excluded from the protection of the refugee regime if they have committed serious crimes against humanity and the purposes and principles of United Nations, ${ }^{25}$ or if they already benefit from other international or national forms of protection. ${ }^{26}$

According to Martin Jones, HRDs would meet the requirements of the 1951 Convention in most circumstances. More specifically, the first condition is fulfilled once a defender leaves his or her country of origin. ${ }^{27}$ Despite the fact that many HRDs face difficulties in leaving their country of origin, as seen elsewhere, neither the method of departure nor the illegal entry or presence plays a role in characterising an individual as a refugee. ${ }^{28}$

As far as the element of the well-founded fear of persecution is concerned, the notion of 'persecution' is rather broad, but it is widely accepted that the concepts of 'persecution' and 'fear of persecution' were intentionally left undefined to make them sufficiently flexible to encompass all forms of mistreatment. ${ }^{29}$ As highlighted from the beginning, defenders are subjected to enforced disappearance, torture, arbitrary arrest, unfair trial and other serious human rights violations. Consequently, these abuses fall within the notion of persecution and enable defenders to satisfy the second element.

However, according to the 'Handbook on the Procedures and Criteria for Determining Refugee Status under the 1951 Convention and the 1967 Protocol relating to the Status of Refugees' produced in 1979 to guide the asylum determination process, individuals who leave

\footnotetext{
${ }^{21} 1951$ Convention (n 18) arts 3-43.

${ }^{22}$ There are authors, including Jones, who use the term 'HRDs at risk' to refer to defenders who put their lives at risk to contribute to the realisation of human rights. However, the author is of the opinion that the term 'HRD' should also include the risk to which a person puts his or her life.

${ }^{23}$ Jones (n 2).

${ }^{24} \operatorname{Art} 1(\mathrm{~A})(2)$ states that ' $[\ldots]$ owing to well-founded fear of being persecuted for reasons of race, religion, nationality, membership of a particular social group or political opinion, is outside the country of his nationality and is unable or, owing to such fear, is unwilling to avail himself of the protection of that country'.

${ }^{25} 1951$ Convention (n 18) art $1(\mathrm{~F})(\mathrm{a}-\mathrm{c})$.

${ }^{26}$ ibid art $1(\mathrm{D})$.

27 Jones (n 2) 940.

${ }^{28} 1951$ Convention (n 18) art 31.

${ }^{29}$ James C Hathaway, 'Reconceiving Refugee Law as Human Rights Protection' (1991) 4 Journal of Refugee Studies 113, 122; Paul Weis, 'The Concept of the Refugee in International Law' (1960) 87 Journal du Droit International 928, 984-86.
} 
their country to escape from prosecution or punishment for a statutory or common law offence or crime cannot be considered refugees. ${ }^{30}$ The logic behind this exclusion is that a refugee is a victim - or a potential victim - of injustice or other violations and not a fugitive of justice. ${ }^{31}$ This proposition relies on Grotius, De Jure Belli ac Pacis, who argued that asylum is to be enjoyed by people 'who suffer from undeserved enmity, not those who have done something that is injurious to human society or to other men'. ${ }^{32}$ Nevertheless, it is worth noting that this argument has been heavily criticised by the European Court of Human Rights (ECtHR) on the basis that it may expose individuals at risk to torture and other forms of inhuman or degrading treatment. ${ }^{33}$ The approach of the ECtHR has paralleled that of the Human Rights Committee in relation to the interpretation of Article 7 of the International Covenant on Civil and Political Rights (ICCPR), which prohibits torture, cruel or inhuman or degrading treatment or punishment. ${ }^{34}$ More specifically, in General Comment 20, the Human Rights Committee stated that '[i]n the view of the Committee, States parties must not expose individuals to the danger of torture or cruel, inhuman or degrading treatment or punishment upon return to another country by way of their extradition, expulsion or refoulement'. ${ }^{35}$

In relation to HRDs this proposition is of great interest as it may result in excluding HRDs from the term 'refugees' because states use legislation against defenders to criminalise their activities. ${ }^{36}$ For this reason it should be necessary for the state of asylum to consider carefully the nature of the offence and the crime presumed to have been committed. The state should establish whether the prosecution is merely a pretext for persecution and, as a result, the applicant is not in reality a fugitive from justice or whether the prosecution is consistent with the standards of international human rights law, and the criminal behaviour does not outweigh the defender's character as a bona fide refugee. ${ }^{37}$

On this basis, defenders subjected to prosecution based on the criminalisation of their activities can also meet the second condition. The second requirement includes the well-grounded fear

\footnotetext{
${ }^{30}$ UN High Commissioner for Refugees (UNHCR), Handbook on the Procedures and Criteria for Determining Refugee Status under the 1951 Convention and the 1967 Protocol relating to the Status of Refugees (re-edited January 1992), UN Doc HCR/IP/4/Eng/REV.1 (UNHCR Handbook), para 56.

31 ibid.

${ }^{32}$ Hugo Grotius, De Jure Belli ac Pacis II, para xvi (cited in Dallal Stevens, UK Asylum Law and Policy: Historical and Contemporary Perspectives (Sweet and Maxwell 2004) 12).

${ }_{33}$ ECtHR, Chahal v United Kingdom, App no 70/1995/576/662, 11 November 1996, paras 98, 102, 108; ECtHR, Vilvarajah v United Kingdom, App no 13163/87, 30 October 1991, para 108; ECtHR, Soering v United Kingdom, App No 14038/88, 25 January 1989.

${ }^{34}$ International Covenant on Civil and Political Rights (entered into force 23 March 1976) 999 UNTS 171 (ICCPR).

${ }^{35}$ UN Human Rights Committee, General Comment No 20 'Article 7 Prohibition of Torture, or Other Cruel, Inhuman or Degrading Treatment or Punishment’ (10 March 1992), UN Doc HRI/GEN/1/Rev.7, para 9.

${ }^{36}$ The criminalisation of HRDs is a major obstacle to their work; see, eg, Inter-American Commission on Human Rights, 'Criminalization of the Work of Human Rights Defenders', 31 December 2015, OEA/Ser.L/V/II. Doc. 49/15 60; and Front Line Defenders, 'Annual Report on Human Rights Defenders at Risk in 2017', 22 January 2018, 7, 15-16, https://www.frontlinedefenders.org/en/resource-publication/annual-report-humanrights-defenders-risk-2017.

${ }^{37}$ UNHCR Handbook (n 30) para 156; Jones (n 2) 941.
} 
of persecution, which is a combination of objective and subjective factors. ${ }^{38}$ Actual or anticipated measures against the defender may establish a well-founded fear, while violations and persecution against similarly situated defenders could also be an indicator. ${ }^{39}$

With regard to the third criterion, a link should be established between the individual's risk of persecution and one of the five reasons for persecution provided by Article 1(A)(2). The element of membership of a particular social group and political opinion seems to apply to defenders in the first place. In particular, with regard to social groups, defenders who fight for particular human rights form and run a group, or preferably organisations committed to the promotion of those rights. The Supreme Court of Canada in Ward established an alternative approach to the meaning of 'membership of a particular social group' ${ }^{40}$ In particular, the Court held that 'the meaning assigned to "particular social group" should take into account the general underlying themes of the defence of human rights and anti-discrimination that form the basis for the international refugee protection initiative' ${ }^{41}$ The Court articulated that it is not possible for every single group of persons to fall within the 1951 Convention refugee definition, as there are some groups in which membership thereof is not fundamental to the defence of human rights and the human dignity of the individuals. ${ }^{42}$ In essence, it is argued that it is the membership of the groups that must be the cause of the risk of persecution and not the individual activities of the claimant. ${ }^{43}$ In the exceptional case of a group that promotes religious rights, membership of the group is not necessary as it is sufficient that the individuals have been found to be at risk of persecution based on activities related to religion, as stated in Article 1(A)(2)(iii).

When it comes to the political opinion of the individual, although some HRDs may not identify their activities as 'political', in practice they act as human rights watchdogs speaking out against human rights abuses and thus play a major role in monitoring the conduct of government officials and other state authorities. In addition, defenders are part of, or they themselves run, organisations fighting for the rights of a particular group, thus satisfying the element of membership of a particular group. Notably, the vast majority of those defenders who took part in the empirical research have been members of NGOs promoting, for example, the rights of LGBTQ people, abandoned children and freedom of expression. In other words, it is argued that by the nature of their work, defenders may express political ideas and as a result meet the requirement of Article 1(A)(2)(iii). This position has also been affirmed by the High Commissioner for Refugees (UNHCR) who accepted that defenders 'may be in need of refugee

\footnotetext{
${ }^{38}$ UNHCR Handbook (n 30) para 52.

39 ibid.

${ }^{40}$ Legal Services Unit of the Immigration and Refugee Board of Canada, 'Interpretation of the Convention Refugee Definition in the Case Law', 31 March 2019, para 4.5, https://irb-cisr.gc.ca/en/legal-policy/legal-concepts/Pages/RefDefPoints.aspx.

${ }^{41}$ Canada (Attorney General) v Ward [1993] 2 SCR 689, 103 DLR (4th 1, 20 Imm L.4 (2d) 85, para 739.

42 ibid 738,745 .

${ }^{43}$ ibid 738-39, 745.
} 
protection on the ground of their [imputed] political opinion and/or their membership of a particular social group' ${ }^{44}$

As is discussed later in this article, much of the academic scholarship has heavily criticised the 1951 Convention for several reasons. One such criticism is that the definition does not include all persons at risk of persecution but accommodates only those at risk of being persecuted because of who they are and what they believe. In fact, the capacity of western states to grant asylum was so inadequate that it forced the drafters to confine the class of refugees on the ground of the five most fundamental principles of non-discrimination in international law. ${ }^{45}$ On this basis, the delimitation of the clause was considered a 'least bad option' ${ }^{46}$ However, the definition does not encompass those individuals fleeing from conditions of serious danger and general harm, such as armed conflict or climate change. ${ }^{47}$ In addition, domestic jurisdictions may adopt a different interpretation; this means that the same requirements may be applied differently across the globe, which may also affect the perception of HRDs as refugees from state to state. In this sense it is argued that the definition of 'refugee' is in need of considerable reform so that it includes individuals at serious risk of persecution who are not currently within the definition. In any case, with regard to HRDs, even the current narrow definition accommodates defenders who wish to apply for asylum in the sense that they are usually persecuted because of their activities as members of groups or for their beliefs.

Moreover, one of the most critical elements is the unwillingness of the state of origin to offer protection to individuals at risk. In relation to HRDs, they may find it harder to meet this criterion, as are those who have spoken out against the state's human rights record and challenged government policy. In essence, the activities of HRDs may be the cause of persecution or risk. On this basis, it would be a paradox if a state that is behind abuses against defenders, or threatens HRDs to stop their activities, were to offer them protection.

Individuals at risk who have committed serious political crimes or crimes against humanity and the principles of the UN cannot benefit from refugee status and, as a result, are excluded from the definition. However, individuals who commit violent crimes cannot by definition be defenders, as violent activities are inconsistent with the requirement of peaceful activities, which is one of the three requirements to be considered a defender, according to the predominant definition of HRDs. ${ }^{48}$ In this sense HRDs easily meet this criterion. Consequently, a defender can be referred to as a 'refugee' and make use of the international refugee regime.

\footnotetext{
${ }^{44}$ UNHCR, Eligibility Guidelines for Assessing the International Protection Needs of Asylum-Seekers from Guatemala (January 2018), UN Doc HCR/EG/GTM/18/01, 39-40.

${ }^{45}$ James Hathaway, 'Special Feature Seventh Colloquium on Challenges in International Refugee Law: Introduction' (2016) 37 Michigan Journal of International Law 229.

${ }^{46}$ James C Hathaway and Michelle Foster, The Law of Refugee Status (2nd edn, Cambridge University Press 2014) 362-441.

${ }^{47}$ Stephen Meili, 'The Constitutional Right to Asylum: The Wave of the Future in International Refugee Law' (2018) 41 Fordham International Law Journal 383, 389.

${ }^{48}$ The definition of the term 'human rights defender' derives from art 1 of the Declaration on HRDs (n 3 ) and is interpreted in the light of Fact Sheet 29 (n 4), which established the three requirements for being considered a defender: (i) a defender should accept the universality of human rights; (ii) the defender's arguments should
} 
Engagement with the international refugee regime entails a number of guarantees of economic, social and cultural rights, and administrative assistance. In particular, Articles 3 to 43 offer various guarantees and rights such as the prohibition of expulsion, ${ }^{49}$ the right to engage in different forms of work, ${ }^{50}$ the right to exercise the person's religion, ${ }^{51}$ and freedom of movement. ${ }^{52}$ In addition, a refugee defender enjoys international recognition and personality and has the right to obtain travel documents $;{ }^{53}$ the principle of comity requires all states to recognise each other's executive and judicial acts, ${ }^{54}$ such as the decision to accept refugee status and the granting of travel documents issued by the asylum state authorities. The point here is that the regime provides more favourable treatment for individuals who apply for asylum and are classified as refugees. As a result, refugee HRDs are entitled to all rights provided by the 1951 Convention.

It is arguable that the status of EHRDs (exiled human rights defenders) could be a more preferred option than refugee status in the sense that these defenders have managed to flee from their country and have been granted visa status, such as work and spousal visas. Indeed, in some states visa status may entail more rights than refugee status. ${ }^{55}$ Visa requirements and the rights that visa status entails are within the scope of immigration laws of states and thus will vary from state to state, while for state parties to the 1951 Convention the requirements for an individual to be classified as a 'refugee' are the same. Also, defenders at risk who need to escape as soon as possible may not have time to apply for a visa and provide the necessary documentation. For these reasons Jones is correct in believing that through the refugee regime HRDs are entitled to privileges to which otherwise they would not be entitled. ${ }^{56}$ However, he acknowledges that 'the protection of the refuge regime is not without difficulty', as states avoid their legal responsibilities towards refugees, impose restrictive domestic legislation, and are not willing to extend protection under the Convention to other individuals at risk. ${ }^{57}$ However, despite his concerns, Jones is of the opinion that 'the refugee regime can offer a meaningful remedy to human rights defenders at risk', ${ }^{58}$

Taking into account the interviews with HRDs, the following sections analyse the validity of this position and conclude that the international refugee regime cannot be seen as an alternative way of protecting HRDs for normative and practical reasons: first, because it is highly flawed and needs improvement in order to accommodate refugees adequately; second, because it does not suit the needs and desire of HRDs to continue their work in their home countries.

not necessarily be factually or legally correct; and (iii) the defender should promote human rights through 'peaceful actions'.

${ }^{49} 1951$ Convention (n 18) art 33.

${ }^{50}$ ibid arts $18,24$.

${ }^{51}$ ibid art 4.

52 ibid art 26.

53 ibid art 28.

${ }^{54}$ Joel R Paul, 'Comity in International Law' (1991) 32 Harvard International Law Journal 1, 5.

${ }_{55}^{55} \mathrm{eg}$, in Germany, those on a spousal visa are on a fast track to naturalisation.

${ }^{56}$ Jones (n 2) 943.

${ }^{57}$ ibid 944, 949.

58 ibid 935. 


\subsection{The International Refugee Regime as a Measure of Last Resort}

HRDs champion and fight for human rights, challenge injustice and government activities, work to raise awareness of abuse against individuals, and hold authorities accountable for their human rights obligations in their country of origin. In other words, the nature of their work is very much connected with the countries in which they live, so leaving that country would have a disastrous impact on the realisation of human rights and the rule of law. Despite the fact that only two defenders said they would apply for asylum if they were at risk, the vast majority perceive that they would be abandoning the persons for whom they fight if they decided to leave their country to seek asylum.

Another participant emphasised that her activity is not illegal in the sense that it would force her to leave her country with a sense of shame; this shows that for some defenders their work is so important that there is no reason to stop doing it, provided that it is not illegal.

It is worth noting, though, that only one defender categorically excludes the possibility of asylum, stating that 'I prefer dying doing what I love', while the majority said they would flee if the situation became very critical. In essence, they want to exhaust all possible means available to them before leaving the country, such as changing strategy or moving to a safer place.

Taking into account that three participants have been granted refugee status, and the vast majority would flee in a critical situation and consider applying for asylum, it can be safely said that the international refugee regime is an alternative. However, it seems from the empirical research that refugee status should be a measure of last resort for this group of people because defenders wish to remain in their country and continue with their work. On this basis, contrary to Jones' opinion that the international refugee regime can provide a meaningful remedy, this option is not suitable for HRDs, and despite the failure of international human rights law to provide efficient protection for HRDs, an alternative form of protection within their countries of origin must be considered.

\section{Flaws in the International Refugee Regime}

\subsection{The International Refugee System and States’ Refusal to Accept Refugees}

The refugee regime does indeed sound like a promising alternative way to protect those defenders who wish to flee from their country to escape from human rights abuses, even as a measure of last resort, given the failure of international human rights law to protect them. However, this section argues that the protection of HRDs through the international refugee regime cannot be a reliable and suitable solution for a further major reason: it relies on a flawed and weak surrogate system, which, as will be seen, is in crisis.

Although refugee protection is a human rights issue of great importance, ironically its objective is not to meet the needs of individuals at risk and provide protection. On the contrary, the purpose of the establishment of the international refugee regime was to ensure the interests of 
powerful states and, particularly, to enable them to address issues of a transnational character and to control enforced migration between states. ${ }^{59}$

During the 1960s and 1970s the international refugee system appeared to be more generous in receiving refugees, as many refugees were the products of anti-colonial movements and wars of national independence. ${ }^{60}$ They were also seen as valuable resources who could contribute to development and boost the economy, and were therefore welcomed by powerful states. ${ }^{61}$ The number of refugees grew dramatically over the following years for several reasons. ${ }^{62}$ Asylum states were becoming extremely worried about receiving massive refugee flows, particularly from the less developed world. ${ }^{63}$ The perception that national sovereignty must be preserved, as well as the idea of protecting prosperity and social coherence, led states to focus on promoting the general well-being of their own populations.

Nowadays, this belief has not changed at all; several states are still tightening their refugee policies or closing their borders to refugees. ${ }^{64}$ Despite international initiatives and agreements to the contrary, ${ }^{65}$ states do their utmost to defend their sovereignty and control the waves of migrants and refugees. In essence, in the context of international refugee law, the intention of

\footnotetext{
${ }^{59}$ James C Hathaway, The Rights of Refugees under International Law (Cambridge University Press 2005) 999; Gil Loescher, 'The International Refugee Regime: Stretched to the Limit?' (1994) 47 Journal of International Affairs 351, 351-53.

${ }^{60}$ Jeff Crisp, 'A New Asylum Paradigm? Globalization, Migration and the Uncertain Future of the International Refugee Regime', UNHCR Evaluation and Policy Analysis Unit, Working Paper No 100, December 2003, 5, http://www.unhcr.org/3fe16d835.pdf.

${ }^{61}$ James C Hathaway, 'A Reconsideration of the Underlying Premise of Refugee Law' (1990) 31 Harvard International Law Journal 129, 177.

${ }^{62} \mathrm{~A}$ great number of people had to leave their countries because of new forms of conflict within the newly established democracies, post-Cold War reformulations, and socio-economic problems in developing countries.

${ }^{63}$ Erika Feller, 'The Evolution of the International Refugee Protection Regime' (2001) 5 Washington University Journal of Law and Policy 129, 134.

${ }^{64}$ See, eg, Stephanie J Nawyn, 'Refugees in the United States and the Politics of Crisis' in The Oxford Handbook of Migration Crises (Oxford University Press 2018)1, 1-18; Francois Murphy and Thomas Escritt, 'Germany, Austria Set Talks with Italy to Shut Southern Migrant Route to Europe' Reuters, 5 July 2018, https://uk.reuters.com/article/uk-europe-migrants/germany-austria-set-talks-with-italy-to-shut-southern-migrant-route-to-europe-idUKKBN1JV2F0; Shaun Walker, 'No Entry: Hungary's Crackdown on Helping Refugees', The Guardian, 4 June 2018, https://www.theguardian.com/world/2018/jun/04/no-entry-hungarys-crackdown-on-helpingrefugees.

${ }^{65}$ The New York Declaration for Refugees and Migrants (New York Declaration) was passed unanimously on 19 September 2016 and was considered a 'game changer', promoting the principles of refugee protection and enhancing the international refugee regime. The Global Compact on Refugees was adopted by the vast majority of states in 2018 with the purpose of providing a basis for predictable and equitable burden, and responsibility sharing among all $\mathrm{UN}$ member states. On the other hand, at the same time several states - such as Hungary, Poland, the United States, Australia and Austria - refused to sign the Global Compact for Migration, which was introduced to boost international cooperation on migration, under the pretext of national sovereignty. The Global Compact on Refugees is in total contradiction to the migration policy of several states. Consequently, it is, in practice, impossible to have a different agenda on issues that are interrelated. See UNGA Res 71/1, New York Declaration for Refugees and Migrants (3 October 2016), UN Doc A/RES/71/1; UNHCR, The Global Compact on Refugees, Draft 3 (4 June 2018), http://www.unhcr.org/events/conferences/5b1579427/official-version-draft-3-global-compact-refugees-4-june-2018.html; UNHCR, The Global Compact on Refugees, Final Draft (26 June 2018), https://www.un.org/pga/72/wp-content/uploads/sites/51/2018/07/Global-Compacton-Refugees.pdf; UNHCR, The Global Compact for Safe, Orderly and Regular Migration, Final Draft (11 July 2018), https://www.un.org/pga/72/wp-content/uploads/sites/51/2018/07/migration.pdf.
} 
protecting the rights of those fleeing from their countries of origin produces a negative tension between the protection of human rights and the preservation of national sovereignty. As the international refugee regime concerns relations between states and how they manage refugee inflows, it is highly unlikely that states will adopt policies that would simplify the asylum process and ensure the rights of refugees, including the rights of refugee HRDs.

\subsection{The Convention relating to the Status of Refugees}

The 1951 Convention is the only binding instrument that addresses the protection of refugees at the international level. ${ }^{66}$ Even though it can be perceived as a 'Bill of Rights' for refugees, ${ }^{67}$ it differs significantly from the traditional human rights treaties as it is more about interstate obligations than individual rights. ${ }^{68}$ In particular, the wording of the majority of its provisions - starting with 'the Contracting States shall accord to refugees', as well as the fact that the term 'rights' referring to refugees is rarely mentioned - leaves no room for doubt that the scheme of the Convention concerns obligations between states. Such normative digression can be justified considering that it was adopted in 1951, several years before the ICCPR, when individuals were not entitled to binding human rights by international convention. ${ }^{69}$

The fact that the 1951 Convention is a duty-based instrument rather than a human rights-based treaty is decisive, as it allows states to keep a distance from their responsibilities. In essence, all duties imposed on states address, in particular, the question of the status of refugees, which means that the state assumes a number of obligations once an individual has been recognised and labelled as a refugee. ${ }^{70}$ In fact, it is at the discretion of the state to grant asylum to an individual as there is no right of an individual to asylum enshrined in the 1951 Convention.

The 1951 Convention imposes on states the prohibition of non-refoulement, which is the most fundamental principle of international refugee law. ${ }^{71}$ In particular, according to Article 33:

\footnotetext{
${ }^{66}$ Based on the 1951 Convention, the regional systems in Latin America and Africa have established their own refugee protection instruments, which are considered to be more generous and hospitable than the international instrument in terms of the notion of 'refugee'.

${ }^{67}$ Brian Gorlick, 'Human Rights and Refugees: Enhancing Protection through International Human Rights Law' (2000) 69 Nordic Journal of International Law 117, 122.

${ }^{68}$ Alice Edwards believes that is a rights-based and rights-granting instrument on the basis that arts 3-34 are of the same nature as some rights granted under various human rights instruments: Alice Edwards, 'Human Rights, Refugees, and the Right “To Enjoy” Asylum' (2005) 17 International Journal of Refugee Law 293; Margaret G Wachenfeld and Hanne Christensen, 'Note: An Introduction to Refugees and Human Rights' (1990) 59 Nordic Journal of International Law 178.

${ }^{69}$ Vincent Chetail, 'Are Refugee Rights Human Rights? An Unorthodox Questioning of the Relations Between Refugee Law and Human Rights Law' in Ruth Rubio-Marin (ed), Human Rights and Immigration (Oxford University Press 2014) 19.

${ }^{70}$ Roger Zetter, 'Labelling Refugees: Forming and Transforming a Bureaucratic Identity' (1991) 4 Journal of Refugee Studies, 39, 39.

${ }^{71}$ Hathaway (n 45) 278-369; McAdam (n 20) 1327; Guy S Goodwin-Gill and Jane McAdam, The Refugee in International Law (3rd edn, Oxford University Press 2007) 201; Elihu Lauterpacht and Daniel Bethlehem, 'The Scope and Content of the Principle of Non-Refoulement: Opinion' in Erika Feller, Volker Türk and Frances Nicholson (eds), Refugee Protection in International Law (Cambridge University Press 2003) 87.
} 
No Contracting State shall expel or return a refugee in any manner whatsoever to the frontiers of territories where his life or freedom would be threatened on account of his race, religion, nationality, membership of a particular social group or political opinion.

In essence, this principle prohibits any act of forcible removal or rejection that can put the individual in danger again. Emphasis should be placed on the consequences of the acts: namely, whether the person's life will be threatened as a result of the state's failure to comply with this prohibition, rather than the nature of the act. ${ }^{72}$ It must be highlighted that the principle of non-refoulement applies to both recognised refugees and asylum seekers as long as they are within the jurisdiction of a state party. The importance of this provision is further endorsed by Article 42, which does not allow states to place any reservation on this principle. It is now widely agreed that the principle against refoulement is a norm emerging from customary international law. ${ }^{73}$

From a conceptual perspective, the prohibition of non-refoulement entails a negative obligation: namely, the obligation to refrain from any act of forcible refusal or rejection. However, the 1951 Convention does not impose the positive aspect of the non-refoulement obligation, which would be the duty to grant asylum. This indicates that the right to grant asylum is a right held by the state. Indeed, the silence on this issue is not accidental as, in order to preserve national sovereignty, states should retain control over who is entitled to be admitted to their territory.

It could be argued that even though there is no de jure right to 'be granted' asylum, there may be an implied right to asylum. ${ }^{74}$ More specifically, Vincent Chetail argues that 'the distinctive nature of non-refoulement and asylum appears highly artificial in practice. Although nonrefoulement is primarily an obligation of result, asylum is generally the only practical means to respect and ensure respect for Article 33'. ${ }^{75}$ In other words, in order to comply with the obligation of non-refoulement, states have the following options: (i) granting asylum and allowing the individual at risk to enjoy those rights enshrined in the 1951 Convention; (ii) granting temporary asylum until the state has examined whether the individual meets the criteria to be considered a refugee under the 1951 Convention; or (iii) sending the individual to another state where there is no risk of persecution. ${ }^{76}$

\footnotetext{
${ }^{72} \mathrm{eg}$, deportation, expulsion, non-rejection at the border or extradition.

${ }^{73}$ Ministerial Meeting of States Parties, Declaration of States Parties to the 1951 Convention and/or its 1967 Protocol relating to the Status of Refugees (13 December 2001), UN Doc HRC/MMSP/2001/09, para 4. The Declaration was endorsed by UNGA Res 57/187 (6 February 2003), UN Doc A/RES/57/187, para. 3; Lauterpacht and Bethlehem (n 71) 87-177.

${ }^{74}$ Terje Einarsen, 'The European Convention on Human Rights and the Notion of an Implied Right to De Facto Asylum' (1990) 2 International Journal of Refugee Law 361; Richard Plender and Nuala Mole, 'Beyond the Geneva Convention: Constructing a De Facto Right of Asylum from International Human Rights Instruments' in Frances Nicholson and Patrick Twomey (eds), Refugee Rights and Realities: Evolving International Concepts and Regimes (Cambridge University Press 1999) 364.

${ }^{75}$ Chetail (n 69) 31.

${ }^{76} 1951$ Convention (n 18) art 31(B).
} 
Article 14 of the Universal Declaration of Human Rights (UDHR) provides for the right of an individual to seek asylum; ${ }^{77}$ therefore this right has implicitly been put into practice and reinforced by the inclusion of the prohibition of non-refoulement, including non-admission at the border. ${ }^{78}$ On this basis, once the Declaration was drafted, the French Ambassador concluded that 'the right to asylum was implicit in the Convention, even if it was not explicitly proclaimed therein, for the very existence of refugees depended on it'. ${ }^{79}$

In the absence of a clear positive obligation to grant asylum, the 1951 Convention gives states a considerable margin of appreciation in deciding how to comply with their obligations. In practice, states have introduced restrictive domestic legislation, such as restrictive interpretation of the definition of refugee, limitations on the right to work, extended visa requirements, and long procedures for identification to discourage people from seeking asylum. ${ }^{80}$ As a consequence, a defender who became involved in the asylum system of a state would live in a perpetual state of uncertainty. Even if the defender is eventually labelled as a refugee, it is questionable whether refugee protection may be considered a human rights remedy. ${ }^{81}$ This, however, exceeds the limits of this article.

The 1951 Convention has also been criticised on the ground that it has no international supervision procedure. The absence of any independent supervisory mechanism is a reflection of the human rights reality of that time. The 1951 Convention was designed to strengthen the protection of individuals fleeing from Nazi, communist and other fascist regimes, and built upon the standards of the time, namely the League of Nations. ${ }^{82}$ On this basis, the General Assembly opted for a subsidiary mechanism that would have responsibility to coordinate international action to protect refugees and resolve refugee problems worldwide. It therefore established the UNHCR. ${ }^{83}$ With the adoption of the human rights covenants and the establishment of treaty bodies monitoring the implementation of the conventions, states familiarised themselves with the idea of interstate supervision of human rights. ${ }^{84}$

\footnotetext{
${ }^{77}$ Universal Declaration of Human Rights, UNGA Res 217A (III) (10 December 1948), UN Doc A/810, art 14(1) of which provides that '[e]veryone has the right to seek and to enjoy in other countries asylum from persecution'. ${ }^{78}$ Edwards (n 68) 301.

${ }^{79} \mathrm{UN}$ Conference of Plenipotentiaries on the Status of Refugees and Stateless Persons, Summary Record of the Thirteenth Meeting (22 November 1951), UN Doc A/CONF.2/SR13 (France).

${ }^{80}$ Crisp (n 60) 8.

${ }^{81}$ James Hathaway, 'Why Refugee Law Still Matters' (2007) 8 Melbourne Journal of International Law, 89, 101.

${ }^{82}$ Guy Goodwin-Gill, 'The Dynamics of International Refugee Law' (2014) 25 International Journal of Refugee Law 651, 655; Jaya Ramji-Nogales, 'Moving beyond the Refugee Law Paradigm' (2017) 111 American Journal of International Law 8, 10.

${ }^{83}$ Statute of the Office of the United Nations High Commissioner for Refugees, UNGA Res 428(V) (14 December 1950), UN Doc A/RES/428(V).

${ }^{84}$ Hathaway believes that the establishment of an additional supervisory mechanism for the 1951 Convention on the model of monitoring treaty bodies would be unnecessary in the sense that the UNHCR seems to be in a more favourable position compared with treaty monitoring mechanisms that rely on the under-resourced UN High Commissioner for Human Rights to support their work: James Hathaway, 'Epilogue: Challenges to the Viability of Refugee Rights' in James Hathaway (ed), The Rights of Refugees under International Law (Cambridge University Press 2005) 995.
} 
Despite the non-binding authority of the UNHCR, the High Commissioner seeks to safeguard the rights of refugees, provide guidance on the interpretation of the 1951 Convention and ensure that refugee law develops consistently with established principles and new challenges. ${ }^{85}$ However, it seems that the role of the UNHCR has changed significantly over the past decades, losing the character of the trustee of refugee rights. More specifically, the agency has now been transformed into a mechanism that is committed primarily to directing a 'refugee protection service delivery', because states have become even more reluctant to resolve refugee crises and call on the agency to avert such crises on their behalf. ${ }^{86}$

What is really absent from the international refugee regime is state accountability within the context of a monitoring body. In particular, the supervisory body seeks to ensure that all state parties comply with their obligations, while all states can hold a fellow state accountable for not complying with its treaty obligations. In essence, the dynamics of 'naming and shaming' and blandishing are those that ensure the protection of human rights within a human rights treaty system. ${ }^{87}$ Consequently, the absence of a normal supervisory institution allows states to keep a distance from their obligations and take little, if any, responsibility for ensuring the rights of refugees.

Although the UNHCR has provided guidance on the interpretation of the 1951 Convention, national authorities and courts have emphasised that its views are of great importance, although not legally binding. ${ }^{88}$ One may argue that the decisions of treaty bodies are not binding either, so an additional monitoring body for the 1951 Convention with non-binding authority would be superfluous. However, it is worth noting that state parties, for instance, to the ICCPR tend to comply with the decisions of the Human Rights Committee, even though they are not legally binding in the sense that they constitute authoritative interpretations of the provisions of the treaty. ${ }^{89}$

Moreover, there is no provision of individual petition to a judicial body similar to those existing under regional treaties, so cases to challenge decisions on applications for asylum and refugee status are heard and decided by national courts. In addition, as there is no relevant provision enshrined in regional treaties, regional courts, such as the ECtHR, may address cases involving asylum seekers and refugees on the basis of violation of human rights contained in the treaties concerned. Notably, regional as well as national courts have produced a large body of case law relating to refugee rights, but these are only disparate decisions and, more importantly, there is no uniformity of approach and reasoning. ${ }^{90}$ In short, the continuing failure to establish a supervisory mechanism on the monitoring treaty bodies model encourages states to avoid taking responsibility for ensuring refugee rights, while also failing to create a common approach to, and case law on, the protection of refugees. It can be said that a supervisory body is unwelcome

\footnotetext{
${ }^{85}$ UNHCR Handbook (n 30).

${ }^{86}$ James Hathaway, 'New Directions to Avoid Hard Problems: The Distortion of the Palliative Role of Refugee Protection' (1995) 8 Journal of Refugee Studies 288.

87 ibid.

${ }^{88}$ Goodwin-Gill (n 82) 655.

${ }^{89}$ Anja Seibert-Fohr, 'The Fight Against Impunity under the International Covenant on Civil and Political Rights' (2002) 6 Max Planck Yearbook of United Nations Law Online 301, 310.

${ }^{90}$ Nuala Mole, Asylum and the European Convention on Human Rights (Council of Europe 2003) 8, 17.
} 
in the eyes of states, as it would challenge the parameters of their refugee policy and have a say in matters relating to state sovereignty.

The UNHCR would also be able to contribute to the protection of those defenders who would be classified as refugees. Besides 'naming and shaming' states that are significantly more hostile towards HRDs seeking asylum, it could provide specific guidance on refugee defenders, emphasising their special needs and dangers. State authorities as well as national and regional courts would be able to handle defenders more effectively, making a real difference in the work and life of HRDs.

\subsection{Europe's Failure in Addressing the Refugee Crisis}

Europe faced its biggest refugee crisis in 2015, when more than 1.3 million people - mainly from Syria, Afghanistan and Iraq - sought asylum in the EU; ${ }^{91}$ this is the largest inflow since the Second World War. Individuals will continue to arrive in Europe seeking asylum for as long as the civil war in Syria and with ISIS is raging, increasing the number of applications for asylum. The EU asylum policy - which is made up of a set of EU laws such as the Dublin Regulation $^{92}$ and the Asylum Procedure Directive - is known as the EU Common European Asylum System (CEAS). The CEAS was established in 2000 with the Eurodac Regulation, which introduced a central registry of fingerprints for all asylum seekers and was further developed in the following year. ${ }^{93}$ Since then it has aimed to ensure that all EU member states protect the rights of those seeking protection under the 1951 Convention and sets out minimum standards and procedures for processing and deciding asylum applications. However, this massive inflow uncovered the inability of European mechanisms to address the unprecedented refugee crisis and the gap in states' asylum policies, despite the uniform EU system. ${ }^{94}$ The purpose of this section is to show how the inability of such a well-developed system as the EU to handle a huge

\footnotetext{
${ }^{91}$ Eurostat, '1.2 Million First Time Asylum Seekers Registered in 2016', 16 March 2017, Doc 46/2017, https://ec. europa.eu/eurostat/documents/2995521/7921609/3-16032017-BP-EN.pdf/e5fa98bb-5d9d-4297-9168-d07c67d1c9e1; Eurostat, 'Statistics Explained: Countries of Origin of (Non-EU) Asylum Seekers in the EU 28 Member States, 2015 and 2016', 15 March 2017, https://ec.europa.eu/eurostat/statistics-explained/index.php/File:Countries_of_origin_of_ (non-EU)_asylum_seekers_in_the_EU-28_Member_States,_2015_and_2016_(thousands_of_first_time_applicants) _YB17.png.

${ }_{92}$ The Dublin Regulation sets out which country is responsible for the examination of asylum claims presented by people who arrive in Europe. On the other hand, the Asylum Procedure Directive, which is a distinct piece of law, is intended to harmonise procedural guarantees and ensure the quality of asylum decision making within the Union: Regulation (EU) No 604/2013 of 26 June 2013 establishing the Criteria and Mechanisms for Determining the Member State Responsible for Examining an Application for International Protection Lodged in One of the Member States by a Third-Country National or a Stateless Person (recast) [2013] OJ L 180/31 (Dublin Regulation); Directive 2013/32/EU of 26 June 2013 on Common Procedures for Granting and Withdrawing International Protection [2013] OJ L 180/60.

${ }^{93}$ See, eg, Council Regulation (EC) No 2725/2000 of 11 December 2000 concerning the Establishment of 'Eurodac' for the Comparison of Fingerprints for the Effective Application of the Dublin Convention [2000] OJ L 316/1; Council Directive 2003/9/EC of 27 January 2003 laying down Minimum Standards for the Reception of Asylum Seekers [2003] OJ L 31/18.

${ }^{94}$ Maryellen Fullerton, 'Refugees and the Primacy of European Human Rights Law' (2017) 21 UCLA Journal of International Law and Foreign Affairs 45, 54-55.
} 
refugee crisis raises questions over the efficiency and reliability of the entire refugee regime as an alternative.

One could argue that the European case study is not indicative because most HRDs would not seek sanctuary in Europe. In fact, given the high rate of violations against HRDs in the Middle East, North Africa and countries in Asia, ${ }^{95}$ it would be highly unlikely they would travel to Europe to seek asylum. However, there are states in Europe that skim the edges of democracy, such as Russia and Turkey, so Europe is still an option for those defenders who wish to flee from Russia or Erdogan's Turkey. In any event, the point of this case study is to highlight Europe's inability to accommodate refugees despite its advanced human rights mechanisms, and by analogy to question the readiness and efficiency of other state parties to comply with the 1951 Convention.

In addition, of the 19 states in the Middle East and North Africa, only six are parties to the 1951 Convention or its 1967 Protocol, while 20 states out of 45 have signed and ratified the Convention in Asia. ${ }^{96}$ This means that those other states are not bound by the 1951 Convention and have their own 'law of asylum' based on a wide variety of sources, such as international human rights law, domestic constitution, local legislation and any other local norms and customs. ${ }^{97}$ In this sense the ability and willingness of those states to accept refugees and, more specifically, refugee defenders is highly questionable.

In 2015 several European countries - including Austria, Sweden and France - refused to accept refugees in the name of national sovereignty and imposed tighter internal border controls in order to avoid becoming a magnet for refugees. ${ }^{98}$ At the same time, EU border states - namely Greece, Italy and Spain - bore the refugee crisis burden in parallel with their financial crises. Given that the Dublin Regulation prevents asylum seekers from choosing the country in which to apply for asylum, ${ }^{99}$ asylum seekers become trapped in the poorest frontline states, which are less developed and equipped to manage such huge numbers of applicants. ${ }^{100}$

Conceiving that it would be impossible for member states to arrive at a wider EU refugee agreement, the EU decided to assist 'frontline' states by offering financial and operational support. ${ }^{101}$ The European Commission established and developed the 'hotspot approach' in order to manage exceptional refugee flows. ${ }^{102}$

\footnotetext{
${ }^{95}$ Front Line Defenders, 'Global Analysis 2020', 28-35, 44-49, https://www.frontlinedefenders.org/sites/default/ files/fld_global_analysis_2020.pdf.

${ }^{96}$ UNHCR, States Parties to the Status of Refugees and the 1967 Protocol, April 2015, https://www.unhcr.org/protect/PROTECTION/3b73b0d63.pdf.

${ }^{97}$ Martin Jones, 'Expanding the Frontiers of Refugee Law: Developing a Broader Law of Asylum in the Middle East and Europe' (2017) 9 Journal of Human Rights Practice 212, 214.

${ }^{98} \mathrm{eg}$, Hungary took the drastic measure of building fences along its borders with Serbia and Croatia to keep out refugees: Ferruccio Pastorea and Giulia Henry, 'Explaining the Crisis of the European Migration and Asylum Regime' (2016) 51 The International Spectator 44, 54.

${ }^{99}$ Dublin Regulation (n 92).

${ }^{100}$ Fullerton (n 94) 56.

${ }^{101}$ It is estimated that Greece had received over 1.3 billion euros by 2020 to manage its refugee crisis.

${ }^{102}$ European Commission, Communication 'A European Agenda on Migration', 13 May 2015, COM (2015) 240 final 5 .
} 
The support given to the hotspot areas operates in certain ways: establishing functional hotspot/refugee camps; registration, identification, fingerprinting and debriefing of asylum seekers; as well as return operations. ${ }^{103}$ The EU agencies Frontex, European Asylum Support Office (EASO), Europol and Eurojust contribute significantly to fulfilling these tasks and providing further assistance in cooperation with local authorities. ${ }^{104}$ Despite the dysfunctionalities of the system, the hotspot approach has improved the rates of registration and fingerprinting of incoming asylum seekers, which is crucial in determining which follow-up procedures to apply. ${ }^{105}$ However, the hotspot approach has received much criticism with regard to the lack of a legal framework to regulate the rights of asylum seekers and the horrific living conditions and poor services in terms of food, water and medication. ${ }^{106}$ Despite the functionality of the hotspot system from an operational perspective, it has fundamental human rights issues. ${ }^{107}$

Asylum seekers are not allowed to leave refugee camps until they have been identified and fingerprinted. This process takes approximately two weeks; therefore, the prohibition on leaving hotspots during this period amounts to de facto detention and is in breach of the right to liberty. ${ }^{108}$

Despite the efforts of the EU, member states have turned their backs on those individuals seeking protection in the first place, thus violating their rights. Images capturing the devastation of the refugee crisis are seen all over the world, casting serious doubts on the leading role of the EU member states as global promoters of human rights.

In times of crisis, minor inconsistencies with human rights obligations may be tolerated on the basis of limited resources against large inflows. Unfortunately, however, it tends to be accepted

${ }^{103}$ European Commission Migration and Home Affairs, 'The Hotspot Approach to Managing Exceptional Migration Flows', 11 September 2015, https://ec.europa.eu/home-affairs/sites/homeaffairs/files/what-we-do/policies/european-agenda-migration/background-information/docs/2_hotspots_en.pdf; Arne Niemann and Natascha Zaun, 'EU Refugee Policies and Politics in Times of Crisis: Theoretical and Empirical Perspectives' (2018) 56(1) Journal of Common Market Studies 3, 5-6.

${ }^{104}$ European Commission Migration and Home Affairs, ibid.

${ }^{105}$ European Court of Auditors, 'EU Response to the Refugee Crisis: The "Hotspot" Approach', Special Report No 06/2017, 68-74, https://op.europa.eu/webpub/eca/special-reports/refugee-crisis-hotspots-06-2017/en; Darren Neville, Sarah Sy and Amalia Rigon, 'On the Frontline: The Hotspot Approach to Managing Migration', European Parliament Policy Department C: Citizens' Rights and Constitutional Affairs, May 2016, http://www. europarl.europa.eu/RegData/etudes/STUD/2016/556942/IPOL_STU(2016)556942_EN.pdf.

${ }^{106}$ Agustín José Menendez, 'The Refugee Crisis: Between Human Tragedy and Symptom of the Structural Crisis of European Integration' (2016) 22 European Law Journal 388, 408; Satoko Horii, 'Accountability, Dependency, and EU Agencies: The Hotspot Approach in the Refugee Crisis' (2018) 38 Refugees Survey Quarterly 204, 204. $107 \mathrm{eg}$, the Moria hotspot (refugee camp on the Greek island of Lesvos) is so overcrowded that it is now two and a half times over its capacity. Asylum seekers do not enjoy a standard of adequate living, personal security and wellbeing, while camps are harmful to the environment and public health. Greece is no exception to the rule; it is rather an indicative example of what happens in other hotspots in Italy and in refugee camps such as that in Calais (France), which is known as the 'Jungle'. See further Anna Papoutsi and others, 'The EC Hotspot Approach in Greece: Creating Liminal EU Territory' (2019) 45(12) Journal of Ethnic and Migration Studies 2200, 2200; Ioanna Pervou, 'Refugees and Vulnerability: The Crisis and the Shift in Human Rights Protection' (2017) 4 Queen Mary Human Rights Law Review 1, 11; Helene Lambert, Paul Tiedemann and Francesco Messineo, 'Comparative Perspectives of Constitutional Asylum in France, Italy and Germany: Requiescat in Pace?' (2008) 27 Refugee Survey Quarterly 16, 25.

${ }^{108}$ Izabella Majcher, 'The EU Hotspot Approach: Blurred Lines between Restriction on and Deprivation of Liberty (Part II)', Border Criminologies Blog, 5 April 2018, https://www.law.ox.ac.uk/research-subject-groups/centrecriminology/centreborder-criminologies/blog/2018/04/eu-hotspot-0. 
that the refugee regime entails a number of serious implications for the human rights of refugees. ${ }^{109}$ It should be noted that individuals seeking protection in Europe face two legal regimes that overlap: one created by the EU; the other one by the Council of Europe. ${ }^{110}$ In this sense the approach of the ECtHR to migration and refugees is rather interesting. In particular, in the case of MSS $v$ Greece and Belgium the ECtHR placed limits on tolerating the predicament of irregular migrants. In particular, the Court examined the legality of the Greek practices regarding registration and identification of irregular migrants and concluded that they constituted a violation of Article 3 of the European Convention on Human Rights (ECHR). It also found that Belgium had failed to comply with the 1951 Convention in that state authorities requested the applicant's return to Greece, despite the fact that they were aware of the terrible conditions in the Greek sites and the applicant's unwillingness to return to Greece. ${ }^{111}$ This approach is of particular interest as it could be extended to refugees.

A point of particular concern is a shift in the Court's jurisprudence with regard to the protection of irregular migrants and refugees. The cases of Khlaifia and Others $v$ Italy and JR and Others $v$ Greece are the most recent illustrations of the current jurisprudence of the ECtHR. In particular, in Khlaifia the Court was called upon to address several issues, such as the violation of the right to freedom of liberty (Article 5) and the conditions of detention in the refugee camps in Lampedusa and Palermo (Article 3).

More specifically, in the case of MSS the Court reiterated the reasoning of Budina and found that refugees are vulnerable human beings by their nature and, as a result, special attention must be paid to their needs. ${ }^{12}$ On the other hand, it was held in Khlaifia that the applicants were young and in good health; they therefore did not come within the notion of 'vulnerable group' and were not in need of special protection. ${ }^{113}$ In short, the ECtHR changed its reasoning, considerably reducing the notion of vulnerability. ${ }^{114}$ Furthermore, the Court highlighted that the facts in question occurred at the time Italy had already been hit by a major migration crisis, so state authorities were under such pressure that there was no room for better conditions. ${ }^{115}$

In the same vein, in the case of JR and Others $v$ Greece the Court decided that the applicants' administrative detention, which lasted for a month, was not arbitrary and could not be considered unlawful under Article 5(1) ECHR. ${ }^{116}$ State authorities took drastic measures to prevent the applicants from staying in Greece unlawfully, guaranteed their deportation, and identified and

\footnotetext{
109 James Milner and Gil Loescher, 'Responding to Protracted Refugee Situations: Lessons from a Decade of Discussion', Refugee Studies Centre, Oxford Department of International Development, University of Oxford, Forced Migration Policy Briefing 6, January 2011, 4, https://www.rsc.ox.ac.uk/files/files-1/pb6-responding-protracted-refugee-situations-2011.pdf.

${ }^{110}$ Fullerton (n 94) 50.

${ }^{111}$ ECtHR, MSS v Greece and Belgium, App no 30696/09, 21 January 2011, para 424.

112 ibid para 253; ECtHR, Budina v Russia, App no 45603/05, 18 June 2009, para 3.

${ }^{113}$ ECtHR, Khlaifia and Others $v$ Italy, App No 14483/12,1 September 2015, para 194

${ }^{114}$ Moritz Baumgartel, 'Facing the Challenge of Migratory Vulnerability in the European Court of Human Rights' (2020) 38 Netherlands Quarterly of Human Rights 12, 23-25.

${ }^{115}$ Khlaifia and Others $v$ Italy (n 113) para 185.

${ }^{116}$ ECtHR, JR and Others v Greece, App no 22696/16, 25 January 2018, para 116.
} 
registered them as part of the implementation of the EU-Turkey Action Plan. ${ }^{117}$ The Court reiterated the Grand Chamber's position in Khlaifia that the undeniable difficulties and inconveniences endured by the applicants stemmed from the situation of emergency confronting Greece at the time the EU-Turkey Statement was implemented. ${ }^{118}$

Several cases are currently pending before the ECtHR concerning the legitimacy of hotspots, the asylum policy and violations of asylum seekers' rights, so the current position of the Court may change in the future. However, this position widens state discretion in taking measures and imposing restrictions on the rights of asylum seekers and refugees, ${ }^{119}$ which could result in small deviations from established human rights obligations. According to Ioanna Pervou, this reasoning 'relativizes human rights protection during severe crises, exactly at the time when protection is needed the most'. ${ }^{120}$ It must also be said that this change in the ECtHR approach shines a spotlight on the need for a supervisory mechanism for the 1951 Convention that would produce a body of case law, establishing a common approach to the interpretation of the Convention and prevent any deviation from its standards.

The crisis in Europe has proved that criticisms of the absence of a supervisory institution, as well as the failure to establish effective transition mechanisms, were well grounded. The failure of the 1951 Convention to establish safe transition routes encourages states to externalise their borders and increase their securitisation. ${ }^{121}$ In this sense some EU states have set up physical barriers, such as fences, to stop individuals at risk from reaching their territory and seeking asylum. It is worth noting that the building of barriers is not illegal under EU law, as each member state has the right to control who enters its territory. ${ }^{122}$ In addition, physical barriers help states to address irregular migration. However, it seems that this measure is inappropriate because it stops not only irregular migrants but also asylum seekers. ${ }^{123}$ Stopping asylum seekers from entering their territory may mean that they end up in non-safe countries or back in their country of origin, which, broadly speaking, would constitute a violation of the principle of non-refoulement. ${ }^{124}$

Such practices render refugees more vulnerable to human trafficking, as they are willing to put their lives and the lives of their families at risk in an attempt to avoid returning back to their country of origin. To be more specific, there are human trafficking networks in Turkey, Greece, Libya and other countries in Europe that charge several thousand euros per person to facilitate the

\footnotetext{
117 ibid para 112 .

118 ibid paras 139, 143; Khlaifia and Others $v$ Italy (n 113) para 185.

${ }^{119}$ Marie-Benedicte Dembour, When Humans Become Migrants: Study of the European Court of Human Rights with an Inter-American Counterpoint (Oxford University Press 2015); Cathryn Costello, The Human Rights of Migrants and Refugees in European Law (Oxford University Press 2015).

${ }^{120}$ Pervou (n 107) 14.

${ }^{121}$ Ramji-Nogale (n 82) 10.

${ }^{122}$ Lyra Jakulevičienè, 'Migration Related Restrictions by the EU Member States in the Aftermath of the 2015 Refugee “Crisis” in Europe: What Did We Learn?' (2017) 3 International Comparative Jurisprudence $222,225$. 123 ibid.

${ }^{124}$ The argument that there is no violation of the prohibition of non-refoulement, because the individual never entered the territory of the state and sought asylum and the Convention does not include a right of entry to an asylum country, is not valid as the individual was prevented from entering the state: ibid 225 .
} 
journey to Europe by providing documents, information and sea passage. ${ }^{125}$ It is no exaggeration to say that states that leave refugees with no other choice feed human trafficking.

This section has proved that the EU and state authorities have been unable and incompetent to deal with the largest inflow of refugees since the Second World War. The fact that such a welldeveloped system as the EU is unwilling to accept refugees and comply with the obligations of its system and the 1951 Convention in the name of sovereignty gives real cause for concern. As a consequence of EU and state policies, a series of violations of the rights of refugees and asylum seekers have occurred, bringing into question the leading role of the EU in the realisation of human rights. Most worryingly, the ECtHR, which can hold states accountable for the violation of refugees' rights within the Council of Europe system, seems to adopt a more tolerant approach to the violation of the rights of refugees and asylum seekers, thus widening states' margin of appreciation. From a moral perspective, the worst aspect of this crisis is that several European states have strongly demonstrated xenophobic attitudes towards refugees, ${ }^{126}$ which shows that the society of those states is unwilling to embrace individuals who are trying to escape from serious violations and danger.

In essence, the refugee crisis in Europe uncovered the inadequacy of the refugee regime and the inhuman attitude of states towards individuals at risk, cultivating suspicion towards the efficiency of the entire refugee regime. Practices and polices such as those implemented in Europe may render defenders seeking asylum more vulnerable and with their rights further violated, which will have a negative impact not only on their lives, but also on the realisation of human rights. For these reasons, seeking protection within the refugee regime cannot constitute a reliable form of protection for those HRDs wishing to flee from their country to escape from violations.

\section{Human Rights Defenders as Refugees}

\subsection{State Reluctance to Take Refugee Human Rights Defenders}

As highlighted above, states perceive refugees as threats to economic and social stability, and refuse to take them in order to preserve their sovereignty. Prejudice against refugees arises from several causes, such as lack of knowledge of their background, fear of cultural change and loss of identity, and lack of respect for different religions and cultures. ${ }^{127}$ Poland, for instance, is one of the most homogeneous countries in Europe, being strongly Polish and Roman Catholic. The reason behind Poland's antipathy towards refugees is the fear that Muslim refugees from Syria, Iraq and Afghanistan could destroy the homogeneity of Polish

\footnotetext{
${ }^{125}$ Patryk Kugiel, 'The Refugee Crisis in Europe: True Causes, False Solutions' (2016) 25(4) Polish Quarterly of International Affairs 41, 50.

${ }^{126}$ Bedrudin Brljavac, 'Refugee Crisis in Europe: The Case Studies of Sweden and Slovakia' (2017) 3 Journal of Liberty and International Affairs 91, 94.

${ }^{127}$ Kees van der Veer and others, 'Cross-National Measure of Fear-Based Xenophobia: Development of a Cumulative Scale’ (2011) 109(1) Psychological Reports 27.
} 
society. ${ }^{128}$ In Greece, there is also a perception that refugees contribute to the spread of communicable disease, even though epidemiologists have made clear that there is very little risk of spreading life-threatening disease to the native population. ${ }^{129}$ In addition, people in the UK believe that refugees have strong links with terrorists, are prone to criminal activities, and reduce property prices. ${ }^{130}$

With regard to HRDs, besides xenophobia, states may be more hostile to refugee HRDs. It is accepted in this article that refugee defenders were formerly individuals who fought for human rights in their country of origin and found themselves to be at such a risk that they decided to flee. They may wish to keep a low profile in order to protect themselves and their family members in the asylum states. ${ }^{131}$ However, it should not be forgotten that these individuals used to play an active role in the struggle against human rights abuses, so they may wish to continue their human rights activities.

In particular, depending on their interests and passions, they may engage with the local community as well as the refugee population, promoting certain human rights or helping local civil society organisations and HRDs. For instance, Dieudonne - a refugee HRD with whom Katie McQuaid talked in the context of several formal interviews and informal conversations between April and October 2012, and who talks about gender issues to the refugee population - stated that: ${ }^{132}$

[p]eople are not reading CEDAW [Convention on the Elimination of all Forms of Discrimination Against Women], protocols and lots of documents. [...]. Women could come with stories of change, one could say: 'Since I started with you and got information about rights I did not know beating a wife is violence, before I thought it was normal, but now I realise it is not normal. He must respect me as a partner'.

Moreover, in the context of the empirical research conducted in 2018, several defenders told the author that even if they were granted refugee status in a state, they would not abandon their fight and the people for whom they fought. In other words, refugee HRDs may wish to remain efficient and continue their fight from a safer place.

States may be more hostile to defenders seeking asylum in the sense that they do not want individuals who may challenge their policies and powerful private corporations with strong relationships with the state, and set the local as well as the refugee population against state authorities. For instance, Uganda has been found to be one of those states that has adopted legislation to target refugees who may challenge state authorities. In particular, Uganda's Refugee Act of 2006 provides that no refugee 'can engage in any kind of political activities within Uganda against any

\footnotetext{
128 Jan Cienski, 'Why Poland Doesn't Want Refugees', Politico, 21 May 2017, https://www.politico.eu/article/politics-nationalism-and-religion-explain-why-poland-doesnt-want-refugees.

${ }^{129}$ Andreas H Eiset and Christian Wejse, 'Review of Infectious Diseases in Refugees and Asylum Seekers: Current Status and Going Forward' (2017) 38(22) Public Health Reviews 1, 7.

${ }^{130}$ Crisp (n 60) 10.

${ }^{131}$ McQuaid (n 17) 18.

132 ibid 17.
} 
country including his own'. ${ }^{133}$ The UNHCR has condemned states that refuse to accept refugees on the grounds that they could change or conceal the political identity of their citizens, or require asylum seekers to cease any activity in order to be considered for refugee status. ${ }^{134}$ The hostility of states towards refugee defenders is not surprising as states tend to be hostile and target defenders who challenge their interests.

Granting asylum to a defender may also harm relations between the asylum state and the state of origin on the basis that the former has harboured an individual who challenged the state's human rights policy and embarrassed his or her state of origin by bringing to the fore human rights abuses and speaking out against its human rights record. For example, Vladimir Lukin, Russian Human Rights Commissioner, argues against Russia granting asylum to Edward Snowden, as 'there are state interests and Russia-US relations could be harmed if Russia grants asylum to Snowden'. ${ }^{135}$ For that reason Snowden should ask an international organisation, rather than Russia, to provide him with a temporary passport and ensure his rights. ${ }^{136}$ It can be said that for two powerful states with conflicting interests and tense relations, such as Russia and the United States, these actions are somewhat provocative. ${ }^{137}$ However, allied states or small developing countries may be reluctant to take in refugee defenders for fear of damaging relations between them or with a powerful state respectively, constituting a further obstacle to relying on the 'refugee solution'.

\subsection{The Situation of Human Rights Defenders as Refugees}

The living and working conditions and the situations of those HRDs who have managed to flee from their country of origin in order to escape from abuses and seek asylum in other countries are so difficult that they provide further evidence that the international refugee regime is not a suitable alternative for defenders.

With the support of civil society organisations, some defenders have managed to remove themselves from immediate danger, seek asylum in another country, be considered refugees and safely relocate to a new place. ${ }^{138}$ However, this is not the case for many HRDs who have not been so lucky and had to rely on being smuggled across borders or to obtain visas and

\footnotetext{
${ }^{133}$ Refugees Act, 2006 (Uganda), art 35(d) and (e).

${ }^{134}$ UNHCR, Guidelines on International Protection No. 9: Claims to Refugee Status based on Sexual Orientation and/or Gender Identity within the context of Article 1A(2) of the 1951 Convention and/or its 1967 Protocol relating to the Status of Refugees (23 October 2012), UN Doc HCR/GIP/12/01, paras 30-33; UNHCR, Guidelines on International Protection No. 13: Applicability of Article 1D of the 1951 Convention relating to the Status of Refugees to Palestinian Refugees (December 2017), UN Doc HCR/GIP/17/13, para 28.

${ }^{135}$ Will Englund, 'Snowden Says He Will Seek Asylum in Russia', The Washington Post, 12 July 2013, https://www. washingtonpost.com/world/snowden-wants-meeting-with-human-rights-activists-lawyers/2013/07/12/237d5254-eac611e2-a301-ea5a8116d211_story.html?utm_term=.7032a3d04d0a.

136 ibid.

${ }^{137}$ Ashley Fantz, Phil Black and Michael Martinez, 'Snowden out of Airport, still in Moscow', CNN, 2 August 2013, https://edition.cnn.com/2013/08/01/us/nsa-snowden/index.html.

${ }^{138}$ Human Rights Council, Report of the Special Representative on the Situation of Human Rights Defenders (1 February 2016), UN Doc A/HRC/31/55/, para 72.
} 
other necessary documents. ${ }^{139}$ The involvement of organised crime in the transportation of defenders, as well as other irregular migrants and refugees, may render defenders even more vulnerable because they face the risk of exploitation and human trafficking.

In order to earn a livelihood and reconstruct their families, defenders often take on low-skilled and low-paid jobs and are excluded from basic labour and social rights. ${ }^{140}$ As a consequence, defenders may abandon their human rights activities, which will have a chilling impact on the human rights movement in the sense that their experience, expertise and advocacy will be lost. ${ }^{141}$

Even more worryingly, the UNHCR has not provided international guidance and training on how state authorities should respond to claims and requests for protection under the umbrella of the term 'human rights defenders'; as a result, UNHCR local branches are unfamiliar with the basis of their claim as defenders. ${ }^{142}$ This has the consequence that the registration process is delayed for years or indefinitely, perpetuating the circle of vulnerability, uncertainty and insufficiency.

In sum, the situation of HRDs as refugees, along with the hostility of states towards refugees and defenders in particular, leaves no room for doubt that the alternative of the international refugee regime will put defenders at greater risk and affect the realisation of human rights.

\section{What is the Best Option for Human Rights Defenders?}

This article has concluded that, for normative and practical reasons, the refugee regime is not an ideal alternative for defenders. However, the question of whether other options exist is tricky when one considers the failure of international human rights law to provide efficient protection in the first place. Making recommendations for the reform of refugee law would not be so relevant to HRDs, as they have appeared reluctant to leave their homes and abandon their fight for human rights. In this sense it is more appropriate to explore reforms that would respond to the needs of defenders within the area of international human rights law. In particular, all types of violation against defenders should be identified along with the failures of human rights law to address them. Only then could relevant recommendations to improve the protection of defenders be made. For instance, in terms of impunity, external pressure from international and regional human rights mechanisms calling on states to comply with their human rights obligations and the development of jurisprudence regarding the right of HRDs would contribute to addressing impunity.

In addition, drawing upon literature on recommendations for strengthening the implementation of human rights law more generally, one could argue that recommendations not strictly related to international human rights law could also be considered as they could contribute to the protection of HRDs. For example, Human Rights Education (HRE) could contribute to

\footnotetext{
${ }^{139}$ Human Rights Council, Report of the Special Rapporteur on the Situation of Human Rights Defenders (16 January 2018), UN Doc A/HRC/37/51, paras 59-60 (Human Rights Council (2018)).

${ }^{140}$ McQuaid (n 17) 16.

${ }^{141}$ Human Rights Council (2018) (n 139) para 37.

142 ibid para 38 .
} 
eliminating the stigmatisation of HRDs, which is essential for their safety and security. ${ }^{143}$ In particular, the aim of the state should focus on preventing human rights violations by effectively teaching citizens the content of human rights, encouraging them to refrain from abuses, and by promoting the realisation of human rights.

Stigmatisation of defenders can occur in several ways, such as criminalisation, smear campaigns and the spreading of lies, and may result in more threats and attacks against defenders. ${ }^{144}$ Education that emphasises the work and status of HRDs would counter such stigmatisation, as it would promote the legitimacy of their human rights practice. In essence, education focusing on the practice of defenders could help people in understanding the nature and significance of their work and prevent them from believing smear campaigns and negative rumours.

State authorities, such as civil servants, members of security forces and jurists, should be familiar with the content of defenders' rights as well as the methods of harassment, so that they know when to abstain from violating the rights of HRDs or how to guarantee their right to promote human rights. In this sense HRE may encourage them to change their professional attitude accordingly. Additionally, HRE, in focusing on the activities of HRDs, may result in a significant reduction of human rights violations.

These measures may require considerable time to become a reality but, once implemented, they will change the situation of defenders dramatically. In the meantime, financial, legal and psychological support is critical for their security, efficiency and well-being, so that defenders can cope with the day-to-day difficulties and risks.

\section{CONCLUSION}

Considering the failure of human rights law to provide sufficient protection for HRDs, the article discussed whether refugee law could be a suitable alternative for those defenders at serious risk. Although refugee law appears to be a safety net in the first place, as defenders share the same characteristics as refugees, it is not an ideal alternative for both practical and normative reasons.

The hostility of states towards migrants and refugees, the inadequacy of the 1951 Convention, Europe's failure to handle the refugee crisis, and the situation of those defenders who left their country and sought asylum leave no room for trust in the refugee system. In fact, refugee law is so problematic that it needs to reform to ensure refugee rights and provide effective protection for

\footnotetext{
${ }^{143}$ Alice M Nah, 'Countering the Stigmatisation of Human Rights Defenders', Centre for Applied Human Rights, University of York, Human Rights Defender Hub, Policy Paper 5, October 2018, https://www.york.ac.uk/media/ cahr/documents/Countering\%20the\%20Stigmatization\%20of\%20Human\%20Rights\%20Defenders, $\% 20$ Human\% 20Rights\%20Defender\%20Policy\%20Brief\%205.pdf.

${ }^{144}$ Inter-American Commission on Human Rights, Criminalization of the Work of Human Rights Defenders, 31 December 2015, OEA/Ser.L/V/II. Doc. 49/15, 60; Sarah M Brooks, “"Troublemakers" and "Foreign Agents": The Situation of Corporate Human Rights Defenders - Submission to the African Commission on Human and Peoples' Rights Working Group on Extractive Industries, Environment and Human Rights Violations', International Service for Human Rights, July 2015, https:/www.ishr.ch/sites/default/files/article/ files/submission_to_the_african_commission_v2.pdf; Protection International, 'Criminalisation of Human Rights Defenders: Categorisation of the Problem and Measures in Response', December 2015, https://www.protectioninternational.org/wp-content/uploads/2012/02/ProtectionInternational_English_Update.pdf.
} 
those individuals at risk. For these reasons, using the refugee regime would mean uncertainty, greater risk and, possibly, further violations against defenders. It should also not be forgotten that it became clear from the talks with HRDs that their top priority is to remain in their home countries and continue their human rights work.

It could be argued that if refugee law manages to fix its own flaws, it could be a more reliable option for HRDs. Even if this were the case, the reluctance of HRDs to leave their activities and abandon their people would never make this an ideal alternative. On this basis, even though the failure of international human rights law to protect HRDs can be used as an argument to dismiss international human rights law as unhelpful, alternatives must be explored within this area of law so that defenders will not reach a point where fleeing from their country is the only choice they have. 